\title{
Information Disclosure, Cognitive Biases and Payday Borrowing
}

\author{
Marianne Bertrand \\ (University Chicago Booth School of Business, NBER, CEPR and IZA) \\ Adair Morse* \\ (University of Chicago Booth School of Business)
}

\author{
First Version: March 2009 \\ This Version: July 2010
}

\begin{abstract}
We study whether additional, psychology-guided information disclosure induces payday borrowers to lower their use of high-cost debt a field experiment at a national chain of payday lenders. We find that information that helps people think less narrowly (over time) about the cost of payday borrowing, and in particular information that reinforces the adding-up effect over pay cycles of the dollar fees incurred on a payday loan in comparison to the fees on other financial instruments, reduces the take-up of payday loans by about 11 percent in a 4 month-window following exposure to the new information.
\end{abstract}

\footnotetext{
${ }^{*}$ Both authors are from the Booth School of Business, University of Chicago, 5807 S. Woodlawn Avenue, Chicago, IL 60637. Contact emails are marianne.bertrand@ChicagoBooth.edu and adair.morse@ChicagoBooth.edu. We thank the Initiative on Global Markets at the University of Chicago, the National Poverty Center at the University of Michigan, the Templeton Foundation, the William Ladany Memorial Faculty Research Fund, the Center for Research on Security Prices, and the Stigler Center for financial support. We also would like to thank a number of people for helpful comments, including John Caskey, Shawn Cole, Todd Gormley, Victoria Ivashina, AnnaMaria Lusardi, Tavneet Suri, Jeremy Tobacman, Peter Tufano, John Zinman, and seminar or conference participants at Booth School of Business, the CEPR-Gerzensee Asset Pricing Week, Copenhagen Business School, the University of Illinois at Chicago, the European Finance Association Summer Meetings, the FDIC-JFSR Bank Research Conference, the Federal Trade Commission, the Milton Freidman Conference on Finance and Development, the National Poverty Center Spring 2009 Conference, the NBER Summer Institute in Corporate Finance, the NBER Behavioral Finance Group, the NBER Household Finance Group, the Norwegian School of Management, the Philadelphia Federal Reserve Conference on Recent Developments in Consumer Credit and Payments, the Stockholm School of Economics and Wharton.
} 


\section{Introduction}

In 2007, Americans paid an estimated ${ }^{1} \$ 8$ billion in financial charges to borrow $\$ 50$ billion from payday lenders. In a typical payday loan transaction, a borrower receives cash from the payday lender in exchange for an authorization to draw the cash advance plus a fixed fee of \$15-\$17 for every $\$ 100$ of loan from the borrower's bank account on the next pay check date. ${ }^{2}$ Annualizing this fee reveals that payday loans are indeed expensive, with implied APRs (annual percentage rates) usually well over $400 \%$. Industry insiders contend that transaction costs are high due to the short-term, high-risk nature of bridge loans. Consumer advocates argue that payday lenders prey on those that are so financially illiterate or unsophisticated that they are willing to take up such expensive loans. This predatory view has motivated some drastic state and federal legislation. For example, Ohio recently enacted a law limiting implied APRs of payday lending to 28\%. At the federal level, the Military Lending Act that took effect in 2007 also caps annual interest rates at $36 \%$ for payday loans made to military personnel and their family. ${ }^{3}$

Empirical research has not been able to ascertain whether such a predatory view of payday lending is warranted. ${ }^{4}$ Indeed, the simple fact that individuals take out payday loans, even for relatively extended periods of time, certainly does not prove that these individuals are being fooled or preyed upon by payday lenders. Individuals might be fully informed about the

\footnotetext{
${ }^{1}$ According to the Los Angeles Times, December 24, 2008.

${ }^{2}$ Technically, payday loans operate on a fee system, not explicit interest rates, which is why usury laws do not apply. However, because they are loans, the implied interest rate is the usual point of reference.

${ }^{3}$ A 36\% APR does not cover default for payday lenders; thus these legislations eliminate payday lending. As a point of reference for the magnitude of payday interest rates, a recent compilation of data collected from 1400 microfinance institutions worldwide concludes that the median microfinance loan is less than $30 \%$ APR and ranges only up to 85\% APR (Rosenberg, Gonzalez, and Narain, 2009). Even with a self-reporting bias, this suggests that payday loans are very expensive on a microfinance scale. Perhaps a more telling comparison would be other feebased finance, such as overdraft and ATM fees.

${ }^{4}$ Morse (2007); Morgan and Stain (2007); Skiba and Tobacman (2007); Melzer (2008), Zinman (2009).
} 
fees associated with payday loans, might not have self-control problems, might not suffer from overly optimistic expectations about their ability to repay these loans, and instead might decide to borrow from payday lenders at high interest rates because they face a pressing need for cash at a moment when they lack access to other, cheaper, forms of financing. ${ }^{5}$

Under the view that the people borrowing from payday lenders are making an informed, utility-maximizing choice given the constraints that they face, one would not expect additional information disclosure about the payday product to alter their borrowing behavior. In contrast, if all or a subset of payday borrowers are cognitively impaired, one might expect borrowing behavior to respond to how the costs (and benefits) of the payday products are being disclosed.

Following this logic, we perform a randomized field trial to evaluate whether and how various ways to present information about the costs of payday loans impact people's decisions to continue borrowing from payday lenders. We design three information treatments that incorporate important behavioral principles from the psychology and economics literatures about the possible cognitive lapses payday borrowers might be making, and ways to de-bias for those lapses. The first treatment strengthens the already existing mandate on APR disclosure on payday loan transactions by directly comparing the APR on a payday loan with the APR on others financial instruments consumers are familiar with - car loan, credit card and subprime mortgage APRs. The second treatment provides borrowers with information about the accumulated fees (in \$ terms) for having a \$300 payday loan outstanding for 2 weeks, 1 month, 2 months, or 3 months (this figure is $\$ 270$ ); this information is compared with information on the equivalent fees for borrowing the same amount on a credit card. The last treatment presents

\footnotetext{
${ }^{5}$ Rampini and Viswanathan (2009, forthcoming) provide a theoretical formalization of why firms or households of low net worth may rationally insure less and be willing to pay very high rates to cover financing needs arising from the durable goods they use in production (for example, borrowing however much is required to fix a broken car when that car is the only way to get to work).
} 
customers with information on the typical repayment profile for payday borrowers, reported in a frequency format, e.g. the frequency distribution of time to repayment of a given loan. In addition to the three information treatments, we also introduce a self control treatment via a savings planner; the goal of including a savings planner is to see whether giving people a tool to help them take active steps to get out of debt can reinforce the effectiveness of information conveyance.

The implementation and evaluation of these various information treatments was made possible because of the unique access we obtained to one the largest payday lending companies in the U.S. Specifically, we were given access to all the customers that entered one of 77 stores of the lender spanning eleven states over a period of two weeks. We randomized the information treatments and planner treatment at the store-day level, thereby eliminating concerns about heterogeneity in the payday borrowing population across stores or days of the week. Approximately four months after the intervention, the lender provided us (after getting consent from the borrowers themselves) with administrative data on all transactions the participating borrowers engaged in with the lender before and after our intervention.

We find that individuals receiving the dollar adding-up treatment are 5.9 percentage points less likely to borrow from the payday lender in the pay cycles that follow the intervention. (This represents an 11 percent decline relative to the control group.) Individuals who receive any of the three information treatments reduce borrowing amounts; in particular, Dollar, APR and Refinancing Information treatments reduce borrowing on average by \$55, \$38, and \$28 respectively in each pay cycle (representing declines of 23, 16 and 12 percent relative to the control). We find no effect of the savings planner on borrowing behavior, and no evidence that the savings planner reinforce the effectiveness of information disclosure. When studying 
heterogeneity in treatment effect across borrower characteristics, we find that borrowers without a college education and those with higher self-control (on two self-reported measures) respond more strongly to the information disclosure.

Hence, in contrast with the view that all payday borrowing reflects informed and rational behavior, our results suggest that information disclosure that is inspired by, and tries to respond to, the specific cognitive biases and limitations that may surround the payday borrowing decision has a non-trivial effect on some individuals' decisions of whether or not to take on a payday loan. Because our information treatments are mixtures of behavioral principles, we cannot isolate a precise mechanism for the borrowers' response. It appears though that getting consumers to think more broadly about the decision to take up a payday loan, either by stressing how the fees accompanying a given loan add up over time or, by presenting comparative cost information to increase evaluability, or to a lesser degree, by disclosing information on the typical repayment profile of payday borrowers results in a reduction in the amount of payday borrowing.

The rest of the paper proceeds as follows. Section II lays out our research design, including a more detailed presentation of the experimental setting and experimental treatments. Survey evidence of the financial literacy of payday borrowers is presented in Section III. Section IV outlines our empirical methodology, and the results are presented in Section V. We conclude (Section VI) with a discussion of the economic magnitude of our results, especially in light of the intense policy debate surrounding the payday lending industry.

\section{Research Design}

\section{Borrowing Process and Intervention}

A quick overview of the payday loan process is useful background information as a precursor to our intervention. When a customer enters a payday loan store desiring, on average, 
to take out a \$350 loan until her next payday, she sees a price schedule of services posted on the wall. The schedule displays the cost of a payday loan as a fee (usually $\$ 15$ - \$17) per \$100 borrowed. This fee does not vary by the length of the loan or borrower risk. The loan duration is set by the individual's pay cycle; loans are always due on the next payday.

The loan process begins when the customer approaches a counter or window where a customer service representative (CSR) works and requests a new loan or a refinancing of an existing loan. The customer provides the lender with a physical copy of her latest bank statement and paycheck stub, and the CSR verifies and updates the employer, income, banking, and personal coordinate information. The CSR takes a few minutes to review the bank account information via a subscriber service and to enter the loan request and borrower information into the system. The company software processes the application and determines whether and how much can be loaned to the customer. (No subjective input enters the loan acceptance process, and local staff cannot influence loan acceptance.) If a loan is offered, the customer signs forms that disclose the terms of the loan and convey the information mandated by State laws, include the APR. The CSR puts the cash and a copy of the paperwork inside a standard size (4 x 9 inch) company envelope and writes the payment due date and amount due on the calendar printed on the outside of the envelope.

We alter or add to this process at two points. First, as the customer hands the application and support materials to the CSR, the CSR asks the customer if she would like to participate in a short 4-question survey in exchange for a year's subscription to a magazine of her choice. The CSR explains that the lender is facilitating research done by the University of Chicago and that the survey answers (which are to be dropped in a survey box in the lobby) will not be recorded by the lender or affect the loan application. If the customer is willing, the CSR directs her to 
check the magazine she desires, sign the consent on the front of the form, and fill out the short survey on the back of the form. At the end of every day, the CSR collects the surveys from the box in the store lobby and writes the customers' identifier code on the survey form so that we can match the information with transaction records from the corporate office. The magazine/consent and survey forms are presented as Figure 1; we discuss the survey questions and responses more at length in our results section.

Our main intervention is to have the CSRs replace the usual cash envelopes with custom envelopes printed with information treatments, which we describe momentarily. We control the envelope implementation by sending each store a packet of materials specific for each date and instruct the store to throw away all materials from the prior day.

\section{Treatments}

We use three different information treatments to be printed on the cash envelopes. These information treatments are presented as Figure 2. A control group receives the regular company envelope.

The first treatment (APR Information Treatment) focuses on the currently used frame for assessing borrowing costs; namely, the APR. State and Federal laws mandate APR disclosure on payday loan transactions, often regulating the form and font size that is used for disclosure. Thus, payday borrowers observe the APR. However, payday loan stores typically post a large pricing menu for their services expressing fees in dollars. It may be that the only cost information that the borrower internalizes is this dollar fee of the loan (e.g., \$15 per \$100 of loan). People might confuse the fee structure they face when taking out a payday loan for the APR. And indeed survey data we report later show that quite a lot of people do just that, saying that the APR on a 
payday loan is $15 \%$. Thus, strengthening the disclosure requirements of the APR might be important in helping borrowers understand the cost of using a payday loan, especially the cost of using it for long-term finance. The information provided under this treatment also directly compares a typical payday lending interest rate (443\%) to interest rates charged on a credit card (16\%), an installment car loan (18\%) and a subprime mortgage (10\%). The point is not to suggest that the borrower could switch to alternative forms of credit; most payday loan borrowers are either near their credit card limits or have credit histories inhibiting mainstream credit entirely. ${ }^{6}$ Instead the goal is to make salient the stark difference in annual rates compared to APRs with which they are more familiar. Such a comparison might be particularly effective if the APR is an attribute that is low in "evaluability," that is an attribute whose fundamental value borrowers cannot easily evaluate in absolute terms, e.g. without a direct reference (anchor) to other related products (Hsee, 1996).

The second treatment (Dollar Information Treatment) compares charges between payday loans and credit cards in terms of dollar costs, rather than annual interest rates. In particular, Dollar Information highlights that whereas the dollar cost in interest of using a credit card to finance $\$ 300$ of debt is $\$ 2.50$ for two weeks and increasing to $\$ 15$ for three months, the cost in fees for a payday loan is $\$ 45$ for two weeks and increasing to $\$ 270$ for three months. This treatment incorporates several behavioral principles which theory suggests might deter payday borrowing. First, as in the APR information treatment, it is possible that the direct comparison to

\footnotetext{
${ }^{6}$ Lawrence and Elliehausen (2008) show that 62 percent of borrowers have been rejected by a credit card. For these constrained borrowers, there are little-to-no other options. However, Agarwal, Skiba and Tobacman (2008) offer new evidence from one (prime) credit card, that a portion of payday borrowers actually do have credit available on their cards when they take out a payday loan, suggesting either that they are making mistakes or that there are other considerations (credit histories, buffer credit, transaction costs, etc.) which make borrowers incur the more expensive costs of payday loan borrowing. Cohen-Cole and Morse's (2010) finding that individual's prefer to pay credit card bills over mortgages because of precautionary liquidity motives may suggest that payday borrowing with some credit available may adhere to rational preference for preserving liquidity. Credit from credit cards is almost instantaneously accessible.
} 
another financial product provide some anchoring that helps borrowers in assessing the fundamental value of payday borrowing. Second, because this treatment forces borrowers to take a broader look at the cost of a payday loan, it may partly undo borrowers' tendency to apply too narrow a decision frame (Kahneman and Lovallo, 1993). This is related to the peanuts effect, in which people do not consider the consequence of a small dollar transaction because small amounts of money are "peanuts" (Markowitz, 1952). Payday borrowers may view each individual cycle fee as peanuts and fail to add up the cost over time. In this regard, this information treatment could be compared to a smoking cessation method of getting a smoker to think about not just the next cigarette, which would have only marginal effect on health, but instead about the next year of cigarette smoking (Read, Lowenstein and Rabin, 1999); it is also related to marketing strategies that temporally reframe transactions from aggregate expenses to a series of small daily expenses, or "pennies-a-day" (Gourville, 1998). Finally, by broadening the time horizon to more than one pay cycle, the Dollar Information treatment might be particularly effective at helping borrowers' overcome a tendency to procrastinate, which is typically more severe when decision periods are short (O’Donoghue and Rabin, 2001).

The third information treatment (Refinancing Treatment) presents a simple graphic of how many times the average person refinances a payday loan before paying it back. The data for the figure are from Lawrence and Elliehausen (2008). This treatment was directly inspired by the de-biasing literature on people's failure to consider adequate variance in future outcomes (e.g., Nisan, 1972; Koriat, Lichtenstein, \& Fischhoff, 1980; Buehler, Griffin, and Ross, 1994). In our case, payday borrowers might be overconfident about their ability to repay a loan quickly or about their future income and expense levels. Building on the findings of Gigerenzer (1991) that overconfidence can be overcome by presenting variance in a frequency form (as opposed to a 
probability), we present customers with information on the typical repayment profile (e.g. a frequency distribution of time to repayment of a given loan) for payday borrowers. Like the Dollar Treatment presented above, this treatment gets borrowers to take a broader look at the payday borrowing decision, and may therefore also partly undo borrowers' tendency to apply too narrow a decision frame. One distinctive feature of this treatment compared to the prior two is that it is based on information (how long it takes people to repay a new payday loan) that is not as easily accessible to payday borrowers (unlike the APR or the dollar fee).

As should be clear from the discussion above, none of these three information treatments can be unambiguously linked to a single behavioral insight or principle. Instead, the treatments are mixtures of different principles combined to achieve as powerful disclosure interventions as possible. This is a feature that our paper shares with other pieces proposing to test in the field the power of behavioral insights for changing individual choices (see for example Benartzi and Thaler, 2004).

We also implement a fourth treatment aimed at empowering thrift. This treatment differs from the first three since the goal of this treatment is to help people take action (possibly in response to the information treatment they were exposed to). Geyskens et al (2007) show that individuals primed with positive associations for certain actions are able to exhibit better selfcontrol. By empowering individuals with a tool for controlling their budgets, our intent is to make payback of loans a positive activity. The Savings Planner, presented as Figure 3, lists possible daily or weekly expenses that a borrower could cut back on to enable saving for the repayment of the payday loan. The objective is for people to think about small changes in habits that could enable saving over time. We suggest a number of daily cutback items such as eating out for lunch, magazines, and lottery tickets. Weekly cutback items might be movies, beauty 
services, sports events, games and DVDs, or car detailing. We leave plenty of space for people to write in their own items. ${ }^{7}$ The Savings Planner is an insert included in the cash envelope. It is brightly colored on firm cardstock and has an attached magnet to make it ready for posting on a refrigerator.

\section{Treatment Randomization \& Participant Characteristics}

We design the experiment to be implemented at 100 stores of a large national payday lending chain. The lender organizes its management into districts of 7-10 stores, mostly contained within a single state. Each store has a store manager and typically 3-5 CSRs, depending on the volume at the location. To facilitate training and greater implementation oversight by district managers, we select districts rather than individual stores to be included in the study. To choose districts, we first include any district that is the only district for a state. ${ }^{8}$ Within the states with multiple districts, we pick districts randomly but restrict each state to a maximum of two districts. We end up covering 11 states, with the minimum number of stores per state being 3 and the maximum being 21 .

The next step is to set up a random application of treatments. Ideally, we would randomly assign treatments as customers arrive at the stores. However, because it would be very difficult for CSRs to accurately keep track of which treatment each customer receives in a hectic store setting, we choose to randomize treatments at the store-day level. ${ }^{9}$ We compensate a loss of power from randomizing at this more aggregate level by having a large sample of stores and by

${ }^{7}$ It is theoretically possible that our decision to include some specific categories of daily and weekly expenses on the planner might in fact have reduced its effectiveness if the listing of such categories inhibited borrowers' ability to retrieve other, non-listed categories from their memory (see e.g. Alba and Chattopadhyay, 1985).

${ }^{8}$ We try to maximize the number of states to provide the sample with the greatest geographic coverage and state law dispersion.

${ }^{9}$ Another concern we had with trying to randomize at the individual level is the possibility of "contamination" between customers. We expect fewer interactions between individuals that come to a store on different days than between customers that come to a store on the same day. 
running the experiment 12 days (Monday - Saturday for two weeks) per store. The algorithm for assigning treatments to store-day combinations forces a dispersion of treatments within stores and across days-of-the-week by not allowing duplicate treatments for any store until all possible combinations of the information treatment and the planner have been assigned once. In the Web Appendix, we report a table of random assignment tests, which show results consistent with successful randomization across a host of socio-economic (from administrative data) and survey variables.

The in-store interventions begin in May 2008 and finish in September 2008. We varied the exact implementation date by district to allow for rolling process of training and support during the program. ${ }^{10}$ The largest wave of interventions (57\% of the final sample) took place between June 2 and June 14, 2008. All but one district of interventions took place before the first week of July. Of the 100 original stores, 23 dropped out of the study, usually by the choice of the store manager. $^{11}$

In total, 1441 individuals of 6538 borrowers whom we asked (i.e., all those successfully taking out a payday loan on implementation days) consented to be included in the study, a $21 \%$ participation rate. In October 2008, ${ }^{12}$ we received a download of all transactions for each of the consenting borrowers. The transaction data contain not just the borrowing amount and borrowing and repayment dates, but also the income and employment data including paycheck frequency. Table 1 present summary statistics of the administrative data, which show that $72 \%$ of borrowers are paid on a similar cycle (bi-weekly or semi-monthly) and that customers borrowed on average 9 times in the prior year, averaging \$372 in loan amount. Most borrowers have well below

\footnotetext{
${ }^{10}$ Each district and store manager participated in both a training conference call and a first week feedback/questions call with the authors and the company's corporate trainer.

${ }^{11}$ Only two of these twenty three told us that they were unable to attract participation.

${ }^{12}$ For the intervention that took place in September, we received this download in January, 2009.
} 
average, but not poverty-level income and have had some college education. Compared with non-participants summary data provided by the store (column 2 of Table 1), study participants only materially differ in income: mean annual incomes are $\$ 30,772$ and $\$ 34,463$ for the participants and non-participants, respectively. ${ }^{13}$

\section{Financial Literacy of Payday Borrowers: Some Survey Evidence}

In October 2008, we conducted a short phone survey of all consenting participants. The phone survey was conducted by PB Research, a firm with experience handling our demographic of customers. Although we asked a number of questions in this survey, we focus here on just three questions, which we use to help further motivate the information treatments described above. The questions concern how much individuals understand about the finance of their transaction. In contrast to other subprime lending, payday lending is widely believed to be a fairly transparent transaction: payday borrowers must all realize that the loan costs $\$ 17$ per $\$ 100$ of borrowed funds. That does not mean, however, that individuals fully digest and comprehend the implication of this fee structure. For example, they may not be aware of how a payday loan compares to other forms of credit in APR because of the emphasis in payday lending on the fee rather than rate, or they may not go through the exercise of adding up the payday fees over periods of refinancing to make the dollar cost salient enough to warrant consideration.

Specifically, the three questions we ask are:

(i) To the best of your knowledge, what is the annual percentage rate, or APR, on the typical payday loan in your area? $\%$

(ii) To the best of your knowledge, how much does it cost in fees to borrow $\$ 300$ for three months from a typical payday lender in your area? \$

\footnotetext{
${ }^{13}$ The analysis is not material different if we estimate models that re-weight participating customers to mimic the income distribution of all customers borrowing from the payday lender on the implementation days.
} 
(iii) What's your best guess of how long it takes the average person to pay back in full a $\$ 300$ payday loan? Please answer in weeks. weeks

Unfortunately, we were only able to reach about $15 \%$ of the participants for this phone survey, or 185 individuals. While this is too low of a participation rate for us to cross this data with our main experimental intervention or to assess how much of the intervention was retained, this survey provides general information about the relevance of cognitive miscomprehension among payday borrowers.

About half of the phone survey participants said they did not know what APR is on the typical payday loan in their area and about 40 percent said they did not know what the fees are for borrowing $\$ 300$ for 3 months. In contrast, most (about 90 percent) provided an answer to question (iii) (how long it takes the average person to pay back in full). Figure 4 presents three histograms corresponding to answers to phone survey questions (i) - (iii), for the people that did provide an answer.

The correct answer for question (i) varies by pay cycle of the individual. Even if we generously say that anyone answering an APR over 180 is correct, the responses are clearly bimodal (first histogram of Figure 4). There is a bulk of people (about 40\%) who know the APR to be high. However, another bulk say the APR is close to the dollar cost per hundred that they borrow (i.e., $17 \%$ APR for a $\$ 17$ per $\$ 100$ loan). It could be that some people did not pay attention to the word "annual" over the phone, but nevertheless, the result is striking.

The second histogram of Figure 4 shows similar bimodality in answers for the add-on fees question (question (ii)). About thirty percent of people get the answer correct (in the \$135\$300 range depending on pay frequency). However, most people answer that the dollar cost of the loan for 3 months is the cost of that loan for one cycle only (e.g., $\$ 45$ to $\$ 51$ in cost for a loan of $\$ 300$ at $\$ 15-\$ 17$ per $\$ 100$ of loan). 
The final histogram shows what people's expectations are concerning the time it takes people to pay back loans (question (iii)). The "correct" answer (from Lawrence and Elliehausen, 2008) is 5-6 weeks. Interestingly, the mean answer is close to that range. But the mean hides quite a lot of variation, with some people providing extremely large numbers: the most common answer is one cycle (2 weeks). ${ }^{14}$

While any inference we can draw from these results is clearly limited given the small sample size and the standard difficulty in getting people to "think hard" in a survey setting where the stakes are low, the histograms do suggest cognitive mistakes and hence room for improved disclosure to affect behavior. Some borrowers appear to confuse the fee structure with the APR, making comparisons across financial products difficult; also, some borrowers might be thinking too narrowly about the cost of payday loans and not internalizing the adding up of costs across multiple cycles of refinancing the same loan.

\section{Empirical Specification}

Our main dependent variable is a dummy variable for whether or not an individual borrows in a given pay cycle (Indicator for Loan). To compute this dependent variable, we start with the entire transaction history (from 2002 until October 1, 2008 for most stores) for each of the 1441 individuals consenting to be in our study. These administrative data contain 39,763 transactions. We then use the time series of pay stub data to impute no payday borrowing in pay cycles where no transaction occurred, filling in 190,099 no payday borrowing cycles and

\footnotetext{
${ }^{14}$ In Figure 4, over $40 \%$ of respondents report the answer as being 2 weeks. Given that over seventy percent of borrowers are bi-weekly or semi-monthly, it must be that a good portion of individuals are not just reporting back their pay cycle. A similar figure plotted for just the bi-weekly and semi-monthly people reflects this: less than half report back their pay period length.
} 
resulting in a panel of 229,862 observations. ${ }^{15}$ In the post treatment period, the control sample borrows 54\% of the time; over the entire sample (e.g. going back to 2002), the average likelihood of borrowing is $17.4 \%$

In our main empirical specification, we use the individual-level panel described above and regress the Indicator for Loan on a set of treatment dummies \{Savings Planner, Dollar Information, APR Information, and Refinancing Information\}, which take the value of 1 in all post-intervention cycles if the individual was exposed to the treatment, 0 otherwise. We include as controls both store*year fixed effects to account for regional fluctuations in borrowing activity and day-of-the-week fixed effects to account for the possibility that different days of borrowing may imply more-or-less constrained borrowing. Finally, we also include individual fixed effects in borrowing activity, but show that our results are roughly unchanged if we ignore them.

Because we rely on individual data but randomize at the store level, we need to account for the correlation of outcomes across individuals within the same store (Moulton, 1990). We do this by allowing for an arbitrary variance-covariance matrix at the store level (e.g. clustering at the store-level). Clustering at the store level also accounts for the possible serial correlation in outcomes both within individuals and within stores in our panel (Bertrand et al, 2004). We also present results of an alternative model where we account for store level unobserved heterogeneity using store random effects.

Finally, we also use as an alternative dependent variable he amount borrowed in any particular cycle (Loan Amount). In this case, we also include the individual's pay cycle income (period income) as a control. Because the majority of observations have zero borrowing, we

\footnotetext{
${ }^{15}$ Technically, the panel is balanced in the time period covered, not in cycles. Weekly pay cycle people have more observations. In estimation, adjusting the weights of observations to balance the panel in cycles does not alter the results, given that 72 percent of the observations are either bi-weekly or semi-monthly.
} 
estimate a Tobit model to handle the truncation. Computationally, we are only able to include store-level fixed effects in the Tobit specification. ${ }^{16}$ We again control for regional economic fluctuations and day-of-the-week borrowing effects with store*year and day-of-the-week dummies. The mean loan amount is $\$ 380$ conditional on there being a positive loan, and $\$ 66$ unconditionally.

\section{Results}

\section{Main Results}

Table 2 displays our main results. For these specifications, we use the "balanced" panel described above and estimate treatment effects across all post-intervention pay cycles. The dependent variable is a dummy variable that equals 1 if the individual borrowed in that cycle, 0 otherwise. As indicated above, all models include day-or-the-week and store*year dummies and a dummy variable that equals 1 if the pay cycle is post-intervention, 0 otherwise.

In the first three columns, standard errors are corrected to account for an arbitrary variance-covariance matrix at the store level (e.g. clustering at the store-level). Column 1 does not include individual fixed effects while column 2 does. Column 3 replicates column 2 but limits the analysis to a one-year pre-intervention period; it may be that individual fixed effects are estimated more meaningfully within a shorter look-back period. We report F-tests for the joint significance of the 3 information treatments, as well as .for the joint significance of the 4 treatments (3 information treatments plus Savings Planner).

As is clear from the Table, our findings are virtually unchanged across these 3

\footnotetext{
${ }^{16}$ We find similar results, with smaller magnitudes due to the truncation, using least squares fixed effects estimates with person fixed effects.
} 
specifications; we focus discussions on column 2. The F-test for joint significance of the treatments has a p-value of 0.084 when testing the information treatments and the saving planner treatments and a p-value of 0.053 when testing just the three information treatments. Looking at the coefficients themselves, we are not able to reject equivalence (in column 2) among coefficient magnitudes in pairwise F-test. However, we find that only the point estimate for the Dollar treatment is consistently significantly different from zero in all estimated models. Hence, it appears that the Dollar treatment mixture of de-biasing the small dollar framing/adding up of costs over time and helping evaluability through comparison to other financial products was most effective at reducing payday borrowing.

As for the magnitude of the point estimate, a one-time intervention reduces the likelihood of borrowing in any cycle post intervention (until October 1,2008 ) by 0.059 . The appropriate comparison is that of the post-intervention control group, for whom there is a 0.542 likelihood of borrowing in a cycle. Thus, the Dollar treatment reduces borrowing by about 11 percent. The APR treatment has a similar magnitude if limiting the analysis to a one-year look-back period (column 3).

Columns 4 and 5 reproduce columns 2 and 3 but use a hierarchical model with store random effects rather than clustering at the store level. The point estimates are virtually identical, as should be expected, but the significance levels are much higher for all information treatments even using the Bonferroni p-values that correct the alpha level for multiple comparison tests. In these hierarchical models, the refinancing treatment (which induces borrowers to think about the future in terms of repayment profiles) has a statistically significant effect on borrowing activity.

Finally, Column 6 confirms that the Savings Planner worked neither independently of the information treatments nor in combination with them to help reduce payday borrowing. Recall 
that we crossed the four levels of the information treatments \{Control, APR Information, Dollar Information, and Refinancing Information\}, with the action treatment \{Control, Savings Planner\}. Our argument for crossing this treatment was the possibility that the Savings Planner might further enable people to react to the information conveyed by the other treatments. As is clear from column 6, we find no evidence of complementarities between the information treatments and the Savings Planner.

Table 3 presents results using the Loan Amount as the dependent variable in a tobit model with store-clustered standard errors. The F-tests again support the view that the information treatments are jointly significant. Column 1 of table 3 reports that all information treatments have a statistically significant negative impact on Loan Amount (and the planner have a positive effect). The largest economic magnitude is for the Dollar treatment, but the other treatment magnitudes are meaningful as well: individuals that receive Dollar (APR) [Refinancing] information treatments borrowed \$55 (\$38) [\$28] less in each post-intervention cycle compared to the individuals that were assigned to the control group, including those that had zero borrowing. The mean control group post-intervention borrowing amount is $\$ 235$; thus this effect represents a 23, (16) [11] percent decline in borrowing after being exposed to the Dollar (APR) [Refinancing] treatment. When limiting the analysis to one year prior (column 2), only the Dollar (with a p-value of 0.054) and APR (with a p-value of 0.076) treatments remain significant.

The analyses in Tables 2 and 3 hold constant the effect of the treatments in each postintervention cycle. In practice though, we would not necessarily expect this effect to be constant. On the one hand, it is possible that the effect of the information is short-lived. This is especially likely since people are only exposed once to the information in the context of our intervention. Of course, this would be different in the case of a real policy change mandating information 
disclosures such as the ones we experiment with. On the other hand, it is possible that it may take time for individuals to react to the information they are exposed to, as they try to make adjustments to their budget to reduce their reliance on payday loans.

In Table 4, we look at the dynamics of the results from Tables 2 and 3, respectively replicating both column 1's from Tables 2 and 3 for the two dependent variables (likelihood of taking up a payday loan and loan amount, clustering at the store level). We separately study how the treatments effect borrowing one cycle post-intervention ( $t=$ intervention cycle +1$), 2$ cycles post-intervention ( $t=$ intervention cycle +2 ), and 3 or more cycles post-intervention ( $t>$ intervention cycle+2; that is until the last period included in the administrative data). The post period is slightly less than four months for most people in the sample.

Although the coefficients are estimated with less precision, it seems that the Dollar treatment takes at least one cycle to take full effect, consistent with the view that it takes some time for people to adjust their budget and manage to pay off their payday loan in response to the information they have been exposed to on intervention day. To see this, note that the coefficient on the Dollar Information Treatment in Column 1 in the first cycle $(-0.035)$ is than that from Table 2 (-0.059); the coefficient grows to a Table 2 comparable magnitude $(-0.064)$ in the second cycle. Qualitatively similar patterns apply in column 2 when we study loan amount in a given cycle. The APR treatment also shows some growing pattern to full effect like the Dollar treatment, but then starts to decline in effect.

Hence, the findings in Table 4 suggest that people may need at least one pay cycle to accumulate funds to pay off their debt, and that these individuals do not revert, at least over a couple of months, to their steady-state level of borrowing. The dynamics we observe certainly 
appear inconsistent with the view that the effects of these treatments are limited to the period when the information is being provided and hence is most salient. Our data do not allow us to study borrowing behavior many months post-intervention, so we cannot comment on what those effects would look like. One should keep in mind that our intervention diverges from a true information disclosure policy change in that, in such a case, individuals would be exposed to the information every time they visit a store.

A key strength of our research design is that we have access to administrative records on payday borrowing activity, and hence do not have to rely on self-reported information. But these administrative records only pertain to the participating lender. It is possible that a portion of the study participants utilize multiple lenders, implying that we might only observe a fraction of total payday borrowing for these individuals. This leads us to consider the possibility that the reduction in borrowing we observe after exposure to some of the information treatments might in fact hide a shift of borrowing towards other lenders. One scenario under which such a shift might happen is if borrowers view our intervention in the payday transaction as paternalistic, blame the participating lender for it, and decide to move more of their business towards competing payday stores.

While this is a reasonable concern, it is important to recall that not all of the treatments we implemented resulted in a reduction in borrowing, even though all could be viewed as paternalistic. For example, we observe no reduction in borrowing activity among those study participants that were handed in a Savings Planner, even though some might see this treatment as especially paternalistic. Also, individuals assigned to the control group were not totally isolated from our intervention in the payday process in that, just like the treated participants, they had to sign the consent form and fill in the short survey about their education level, self-reported self- 
control and planned usage for the payday loan.

Nevertheless, we address this concern more directly by collecting information on the number of competing payday stores in each of the 77 participating stores' zip codes. Quite naturally, we hypothesized that borrowers' ability to move their business to another store would be constrained by the number of competing stores in the area. Hence, it made sense to replicate our analysis in the less competitive areas where the change in payday borrowing we observe ought to be much closer to the total change in payday borrowing.

We obtained information on number of competing stores by zip code from the directories of payday stores that are maintained by the bank regulator in each State (some of which we could directly download from the web, others we had to call the States to obtain). We were unable to obtain reliable information for one State and thus dropped it from the analysis. We re-estimate our preferred specifications (columns 2 of Table 2 and column 1 of Table 3 ) on the subset of five stores that do not have any competitors in their zip code (66 people), as well as on the subset of eleven stores that have only one or two competitors in their zipcode (245 people). In both of these rather small subsets of the data, we found the economic and statistical significance of our most powerful treatment (stressing the adding-up fees of multiple cycles of refinancing) to be as large as that of the full sample. All the other treatments were statistically insignificantly different from 0. Overall, these results seem consistent with the view that the reduction in payday borrowing activity we observe applies to total payday borrowing, and is not simply a reallocation of borrowing towards other stores. 


\section{Heterogeneity of Effects across Groups of Borrowers}

In this final section, we ask whether information disclosure differentially impacts individuals according to the information they provided on the in-store survey. The survey allows us to explore four dimensions of heterogeneity. First, we know each participant's educational attainment level - high school or less, some college, or college degree or higher. Second, we have the self-reported ranking of self control attributes (with questions from Puri, 2001), from which we can create a self-control scale $=+$ a planner + self-controlled - impulsivity - enjoys spending. Third, we have a discrete measure of whether the payday loan funds are for gratification items (gifts, apparel, electronics, eating out or vacations), as identified in Parker (1999) and Souleles (1999). ${ }^{17}$ Fourth, customers provided estimates as to how long it would take them to repay the loan. For this last dimension though, perhaps due to poor wording of the question, the majority of individuals responded exactly the length of the loan term; thus, the best we can do is to categorize those who expect a longer than one pay cycle payback time (measured as $>1.33 *$ cycle to handle weekends) into the category of "long expected payback time" individuals. All these measures, except maybe the self-control scale, represent "discrete classes” along the definitions of Gangestad and Snyder (1985), and we thus perform the heterogeneity analysis by splitting the data into subclasses of individuals. ${ }^{1819}$

\footnotetext{
${ }^{17}$ If individuals choose more than one usage category, we coded gratification equal to one if any of the gratification items was checked. Nine percent of individuals fall into our gratification types. Our initial motivation for isolating these specific usage items comes from Souleles (1999) and Parker (1999)'s studies of consumption out of tax windfalls. In particular, contrary to the permanent income hypothesis, Souleles and Parker document jumps in consumption for vacations (Souleles) and entertainment and apparel (Parker) for unconstrained individuals after the unexpected positive income shocks. Similarly, Bertrand and Morse (2009) show that individuals who reported using the payday loan for one of these gratification usage categories used virtually none of their 2008 tax rebate to pay down their payday loan debt.

${ }^{18}$ The literature vigorously criticizes split analyses and, in particular, dichotomizing continuous variables because of the loss of power and possible bias (Maxwell and Delaney, 1993; Irwin and McClelland, 2001). However, split analyses can be appropriate if the underlying trait is categorical (MacCallum, Zhang, Preacher, and Rucker (2002) DeCoster, Iselin and Gallucci (2009)). In the end, we chose to also perform the median split on the (more)
} 
In Table 5, we replicate column 1 of Table 2 for the sub-groupings identified above. ${ }^{20}$ Columns 1 to 3 focus on education: the dollar information treatment is least effective at reducing borrowing among the most highly educated borrowers (significantly less so than for the other education levels). The next 4 columns of Table 6 focus on heterogeneity of response by selfcontrol. The general message is of a larger point estimate and more precise response to the Dollar Information treatment among individuals with higher self-reported self-control levels, or those not using the loan for gratification purposes. Conversely though, the APR treatment appears more effective for those scoring lower on the self-reported self-control scale. Finally, columns 8 and 9 show no significant difference in treatment effects for those who do not expect to quickly pay off the loan.

\section{Conclusion}

Even though the payday product appears quite transparent (especially when compared to other consumer financial products), our results suggest that information disclosure that is inspired by, and responds to, cognitive biases or limitations that surround the payday borrowing decision has a significant effect on individuals' decisions of whether or not they end up taking out a payday loan. In particular, getting consumers to think more long-term about the adding-up of the dollar costs over time, putting the loan in context of comparative products to increase its evaluability, and, to a lesser degree, disclosing information on the typical profile of payday loan refinancing significantly reduces the frequency and amount of payday borrowing.

continuous self-control scale, both for the sake of a succinct exposition and for practicality: indeed, in a non-split model, we need to include both interactions of the treatments with the trait in question, but also interactions of the all the control variables (in our case, vectors of fixed effects) with the trait.

${ }^{19}$ Summary statistics and correlations among these variables are available on the Web Appendix.

${ }^{20}$ In regressions not reported here, we also replicated column 6 of Table 3 (e.g. tobit model for amount borrowed). The results were qualitatively similar to those we report in Table 6 . 
Taken at face value, those convinced that close to all payday borrowing is irrational might perceive a 11 percent reduction in borrowing as a disappointing result for information disclosure and as an indication that more extreme measures (such as an altogether ban on payday lending) might be required. Such a perception of failure might be reinforced by the fact that the information disclosure interventions we experimented with are quite powerful in comparison with the more standard "Truth-in-Lending Act (TILA)-style" disclosure procedures one may expect from the regulatory process. $^{21}$

This paper though started from the premise that payday borrowing need not be irrational. We view it as an open question whether a majority of borrowers did not respond to the disclosure interventions because they already acted optimally (and the additional information was therefore irrelevant to them) or because the interventions were too weak to cognitively de-bias them. So, we remain agnostic as to rendering judgment on the sufficiency of disclosure as a "remedy" to payday borrowing.

It is, however, important to cast the 11 percent reduction in borrowing in the light of the low cost and benign nature of information disclosure, relative to the main policy alternatives. An altogether ban on payday borrowing may leave stranded many households facing true emergencies, e.g. without access to the funds needed to get their car fixed to make it to work or to receive urgent medical care. Financial education programs, while they have the potential to help participants in their budgeting decisions and their general understanding of an increasingly large and complicated menu of debt and investment products, are quite expensive and may not be

\footnotetext{
${ }^{21}$ This is true both in terms of the substance of the disclosure (we rely on strong guidance of behavioral principles) but also in terms of style (we use large fonts and colorful prints on the back of cash-containing envelopes).
} 
able to reach the most at-risk groups. ${ }^{2223}$

Finally, while the disclosure interventions we presented in this paper might be more “flashy" than what typically comes out of the regulatory process, there are also reasons to believe that a formal disclosure policy might be more effective than our experimental interventions. In particular, a formal policy would imply a permanent change, which could strengthen the effectiveness of the disclosure thanks to repeated exposure. Also, we did not benefit from the ability to pilot alternative versions of our disclosure treatments: while all were inspired by behavioral principles, slight changes in the operationalization of these principles might have large effects in practice. Formal policy would hopefully be guided by the cumulative learning across multiple studies such as ours.

\footnotetext{
22 See Lusardi and Mitchell (2004; 2007), Bernheim and Garrett (2003), Lusardi and Tufano (2008) for evidence of a relationship between financial literacy and financial decision-making. See also Bernheim, Garrett and Maki (2001) and Cole and Shastry (2008) for discussion of causality.

${ }^{23}$ For example, Meier and Sprenger (2008) find that individuals that choose to participate in a financial counseling program have lower discount rates than those that choose not to participate.
} 


\section{References}

Agarwal, S., P.M. Skiba and J. Tobacman, 2008. Payday Loans and Credit Cards: New Liquidity and Credit Scoring Puzzles? Working Paper.

Alba, J. W. and Chattopadhyay, A. 1985. Effects of Context and Part-Category Cues on Recall of Competing Brands. Journal of Marketing Research. 22, 340-349.

Benartzi, S., and R.H. Thaler, 2004. Save More Tomorrow: Using Behavioral Economics to Increase Employee Savings. Journal of Political Economy. 112, S164-S187.

Bernheim, B. D., Garrett, D. M., 2003. The determinants and consequences of financial education in the workplace: Evidence from a survey of households. Journal of Public Economics. 87, 1487-1519.

Bernheim, B. D., Garrett, D.M., and Maki. 2001. Education and saving:: The long-term effects of high school financial curriculum mandates. Journal of Public Economics. 80, 435-465.

Bertrand, M., E. Duflo and S. Mullainathan, 2004. How Much Should We Trust Difference-inDifferences Estimates. Quarterly Journal of Economics, 119(1): 249-275,

Bertrand, M., Morse, A., 2009. What Do High-Interest Borrowers Do With Their Tax Rebate? American Economic Review. forthcoming.

Buehler, R., Griffin, and Ross, 1994. Exploring the "planning fallacy": Why people underestimate their task completion times. Journal of Personality and Social Psychology. 67, 366-381.

Cole, S., Shastry, G. K., 2008. If You Are So Smart, Why Aren't You Rich? The Effects of Education, Financial Literacy and Cognitive Ability on Financial Market Participation. Working Paper.

Cohen-Cole, Ethan and Jonathan Morse, 2010. Your House or Your Credit Card, Which Would You Choose? Personal Delinquency Tradeoffs and Precautionary Liquidity Motives. Working Paper.

DeCoster J, Iselin AM, Gallucci M., 2009. A conceptual and empirical examination of justifications for dichotomization. Psychological Methods. 14(4):349-66.

Elliehausen, G., E. C. Lundquist and M. E. Staten, 2007. The Impact of Credit Counseling on Subsequent Borrower Behavior. Journal of Consumer Affairs. 41, 1-28.

Gangestad, S. W., Snyder, M. 1985. To carve nature at its joints: On the existence of discrete classes in personality. Psychological Review, 92, 317-349. 
Geyskens, K., M. Pandelaere, S. Dewitte and L. Warlop, 2007. The Backdoor to Overconsumption: The Effect of Associating “Low-Fat” Food with Health References. Journal of Public Policy \& Marketing. 26, 118-125.

Gigerenzer, G., 1991. How to make cognitive illusions disappear. European Review of Social Psychology. 2, 83-115.

Gourville, J.T. 1998. Pennies-a-Day: The Effect of Temporal Reframing on Transaction Evaluation. Journal of Consumer Research. 24, 395-408.

Hoch, S. J., Loewenstein, G. F., 1991. Time-Inconsistent Preferences and Consumer Self-Control. Journal of Consumer Research. 17, 492-507.

Hsee, C. K. 1996. The Evaluability Hypothesis: An Explanation for Preference Reversals between Joint and Separate Evaluations of Alternatives. Organizational Behavior and Human Decision Processes. 67, 247-257.

Koriat, A., Lichtenstein, and B. Fischhoff, 1980. Reasons for confidence. Journal of Experimental Psychology: Human Learning \& Memory. 6, 107-118.

Kahneman, D. and D. Lovallo, 1993. Timid choices and bold forecasts: A cognitive perspective on risk and risk taking. Management Science. 39, 17-31.

Lawrence, E. C. and Elliehausen, G., 2008. A Comparative Analysis of Payday Loan Customers. Contemporary Economic Policy, 26(2), 299-316.

Lusardi, A., Mitchell, O., Saving and the Effectiveness of Financial Education. In: O. Mitchell, S. P. Utkus, Eds.), Pension Design and Structure: New Lessons from Behavioral Finance. Oxford University Press, Oxford, 2004, pp. 157-184.

Lusardi, A., Mitchell, O., 2007. Financial Literacy and Retirement Planning: New Evidence from the Rand American Life Panel. Working Paper.

Lusardi, A., Tufano, P., 2008. Debt Literacy, Financial Experience, and Overindebtedness. Working Paper.

MacCallum, R. C., Zhang, S., Preacher, K. J., \& Rucker, D. D. 2002. On the practice of dichotomization of quantitative variables. Psychological Methods, 7, 19-40.

Maxwell, S. E., \& Delaney, H. D. 1993. Bivariate median splits and spurious statistical significance. Psychological Bulletin, 113, 181-190.

Markowitz, H., 1952. The utility of wealth. Journal of Political Economy. 60, 151-158.

Meier, S., Sprenger, C., 2008. Discounting Financial Literacy: Time Preferences and Participation in Financial Education Programs. Working Paper. 
Melzer, B., 2008. The Real Costs of Credit Access: Evidence from the Payday Lending Market. Working Paper.

Morgan, D. P., Strain, M. R., 2007. Payday Holiday: How Households Fare after Payday Credit Bans. Federal Reserve Bank of New York Working Paper.

Morse, A. 2007. Payday Lenders: Heroes or Villains? Working Paper.

Moulton, B. R., 1990. "An Illustration of a Pitfall in Estimating the Effects of Aggregate Variables on Micro Unit," The Review of Economics and Statistics, vol. 72(2), pages 334-38

Nisan, M., 1972. Dimension of time in relation to choice behavior and achievement orientation. Journal of Personality and Social Psychology. 21, 175-182.

O’Donoghue, T. and M. Rabin. 2001. Choice and Procrastination. Quarterly Journal of Economics. 116, 121-160.

Parker, J. A., 1999. The Reaction of Household Consumption to Predictable Changes in Social Security Taxes. American Economic Review. 89, 959-973.

Puri, R., 1996. Measuring and Modifying Consumer Impulsiveness: A Cost-Benefit Accessibility Framework. Journal of Consumer Psychology. 5, 87.

Rampini, A and S. Viswanathan. Forthcoming. Collateral, risk management, and the distribution of debt capacity. Journal of Finance.

Rampini, A and S. Viswanathan. 2009. Household risk management. Duke University Working Paper.

Read, D., G. Lowenstein and M. Rabin, 1999. Choice bracketing. Journal of Risk and Uncertainty. 19, 171-191.

Rosenberg, Richard, Adrian Gonzalez, and Sushma Narain. 2009. The New Moneylenders: Are the Poor Being Exploited by High Microcredit Interest Rates? Occasional Paper 15. Washington, D.C.: CGAP.

Skiba, P. M., Tobacman, J., 2007. Do Payday Loans Cause Bankruptcy? Working Paper.

Souleles, N. S., 1999. The Response of Household Consumption to Income Tax Refunds. American Economic Review. 89.

Zinman, J. 2009. Restricting Consumer Credit Access: Household Survey Evidence on Effects around the Oregon Rate Cap. Journal of Banking and Finance, 34(3), March 2010, 546-556. 
We are researchers at the Graduate School of Business at the University of Chicago. We are asking you to participate in a research study on payday lending. The objective of the research is to better understand the context in which people use payday loans. Participation in the research will involve: 1) a five-question survey now (see page 2) a follow-up 5 to 10 minutes phone survey two months from now. You may refuse to answer any question on the surveys.

We will also link your survey answers to information

Your name or other identifiers will not be attached to your answers so that your confidentiality can be maintained. Your privacy will further be ensured in that all data resulting from this study will be analyzed, written, and published in aggregate form. The payday lender will not be given access to the individual-level data resulting from this study.

Your participation is voluntary and refusal to participate does not involve any penalty. You may discontinue participation at any time. In particular, your decision of whether or not to participate in this research or to discontinue your participation will in no way affect your access to the services of this payday lender or other payday lenders. your survey answers will not affect the terms of the current loan or any future loan at this payday lender. Participating in this research involves mininal risks.

If you agree to participate in this study, you will be offered a one-year subscription to one of the [5] magazines below - please check the magazine of your choice:
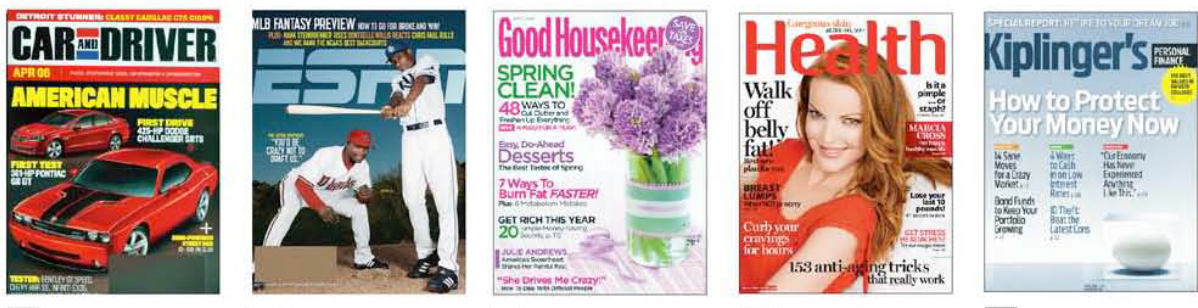

A copy of this consent document is available to you for your records if you so choose.

\section{DO YOU WISH TO PARTICIPATE IN THIS STUDY?}

Name

Signature

Date:

If you have any questions or concerns about the research you may contact: Marianne Bertrand 5807 S. Woodlawn Chicago, IL 60637

If you have any questions about your rights as a participant in this research, you can contact:

Social \& Behavioral Sciences IRB University of Chicago, 5835 S Kimbark - Judd 333 Chicago, IL 60637

Phone: (773) 834-7835, Fax: (773) 834-8700 Email: sbsirbwise@listhost.uchicago.edu 
Figure 1 (continued): Survey Form (flip side of Consent form)

\section{Survey}

What expenses did you originally take out the loan for (if renewing) or what will you use this loan for (if new loan).

Please check all that apply.

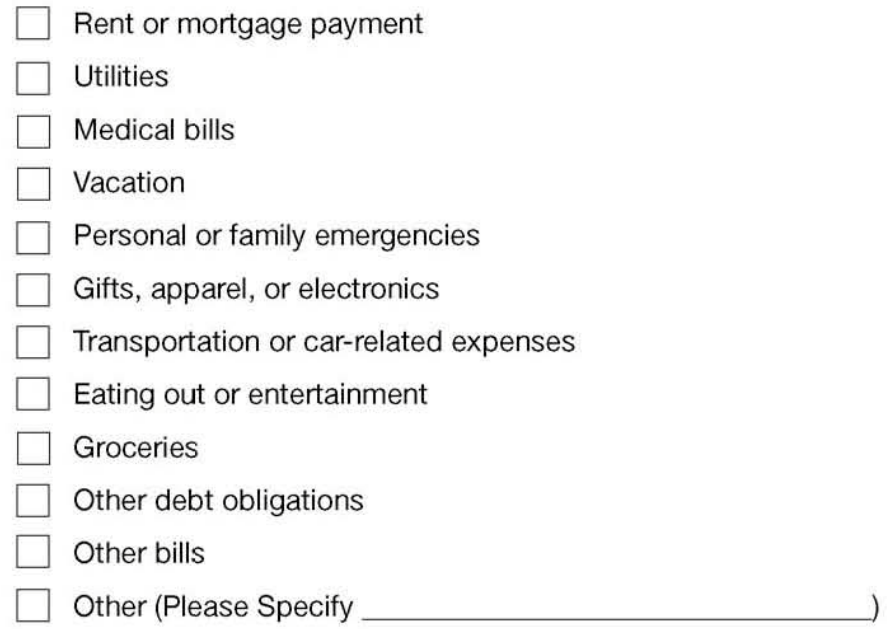

What is your highest level of education?

Less than high school degree

High school degree or equivalent

Some college

Bachelor'sdegree orhigher

How many weeks do you think it will take for this loan to be paid back in full?

Weeks

Indicate how well each of the following adjectives would describe you. On each row, circle the number most appropriate for you on the scale next to each adjective.

Numbers near 1 indicate that the adjective would seldom describe you, numbers near 4 indicate that it would sometimes describe you, and numbers near 7 indicate it would usually describe you.

\begin{tabular}{|c|ccccccc|}
\hline & $\begin{array}{c}\text { Seldom would } \\
\text { describe me }\end{array}$ & & $\begin{array}{c}\text { Sometimes would } \\
\text { describe me }\end{array}$ & $\begin{array}{c}\text { Usually would } \\
\text { describe me }\end{array}$ \\
\hline A Planner & 1 & 2 & 3 & 4 & 5 & 6 & 7 \\
\hline Impulsive & 1 & 2 & 3 & 4 & 5 & 6 & 7 \\
\hline $\begin{array}{c}\text { Self } \\
\text { Controlled }\end{array}$ & 1 & 2 & 3 & 4 & 5 & 6 & 7 \\
\hline $\begin{array}{c}\text { Enjoy } \\
\text { Spending }\end{array}$ & 1 & 2 & 3 & 4 & 5 & 6 & 7 \\
\hline
\end{tabular}


Figure 2: Information Treatment Envelopes
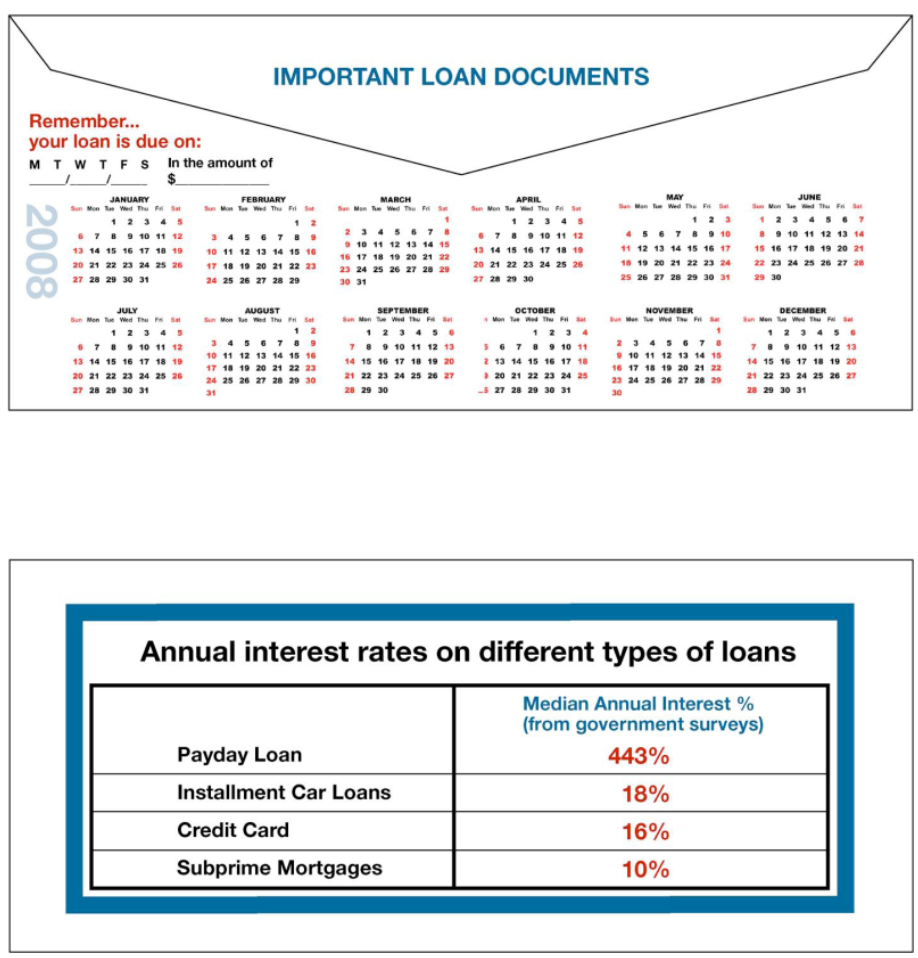

How much it will cost in fees or interest if you borrow $\$ 300$

\begin{tabular}{|cc|cc|}
\hline $\begin{array}{c}\text { PAYDAY LENDER } \\
\text { (assuming fee is } \$ 15 \text { per } \$ 100 \text { loan) } \\
\text { If you repay in: }\end{array}$ & \multicolumn{2}{|c|}{$\begin{array}{c}\text { CREDIT CARD } \\
\text { (assuming a 20\% APR) }\end{array}$} \\
\hline If yeeks & $\$ 45$ & 2 weeks & $\$ 2.50$ \\
\hline 1 month & $\$ 90$ & 1 month & $\$ 5$ \\
\hline 2 months & $\$ 180$ & 2 months & $\$ 10$ \\
\hline 3 months & $\$ 270$ & 3 months & $\$ 15$ \\
\hline
\end{tabular}

Out of 10 typical people taking out a new payday loan...

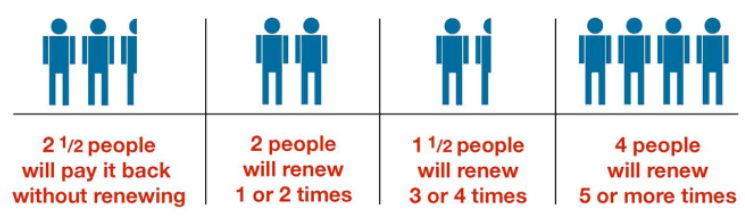


Figure 3: Savings Planner Treatment

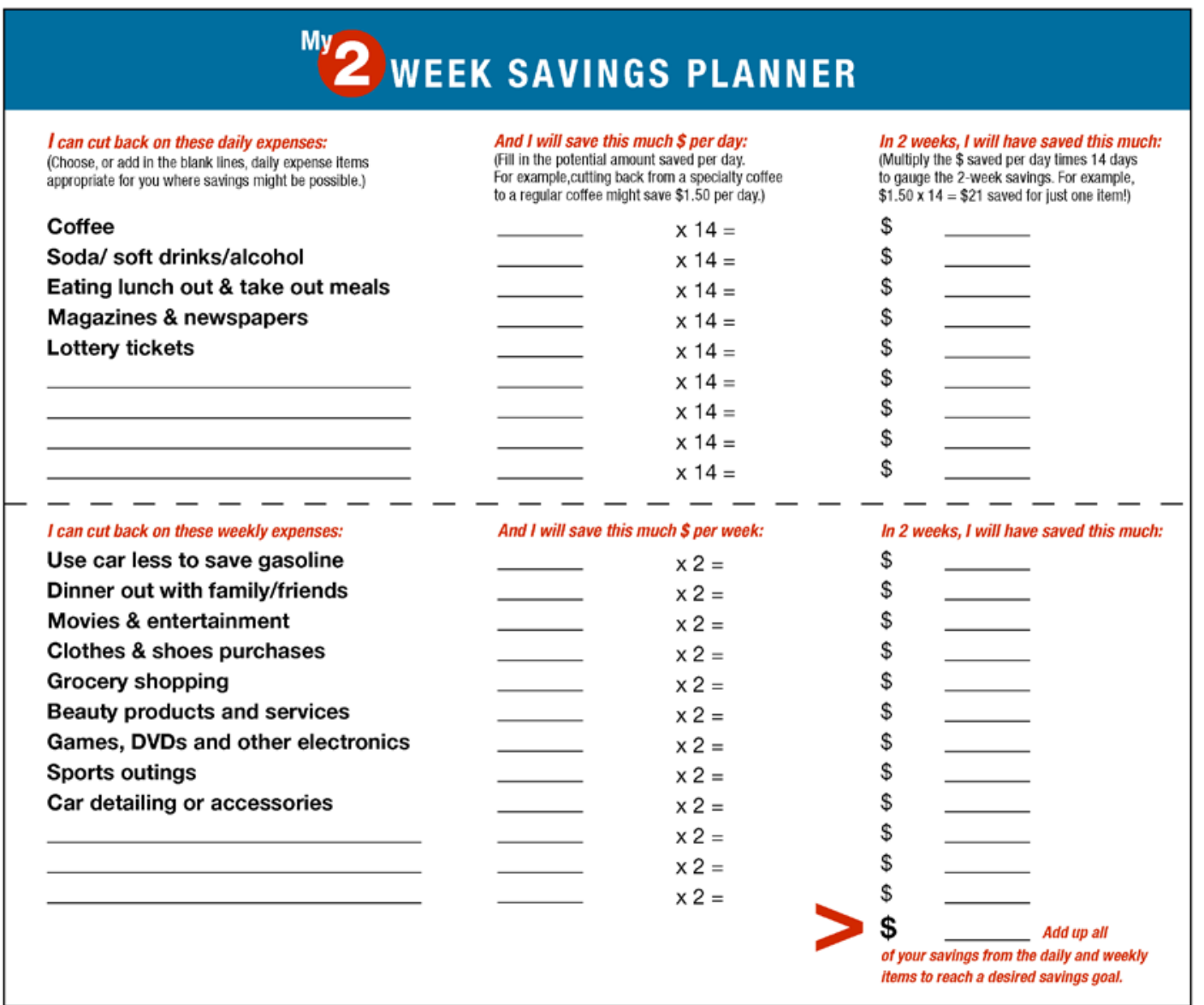


Figure 4: Phone Survey Financial Literacy Histograms

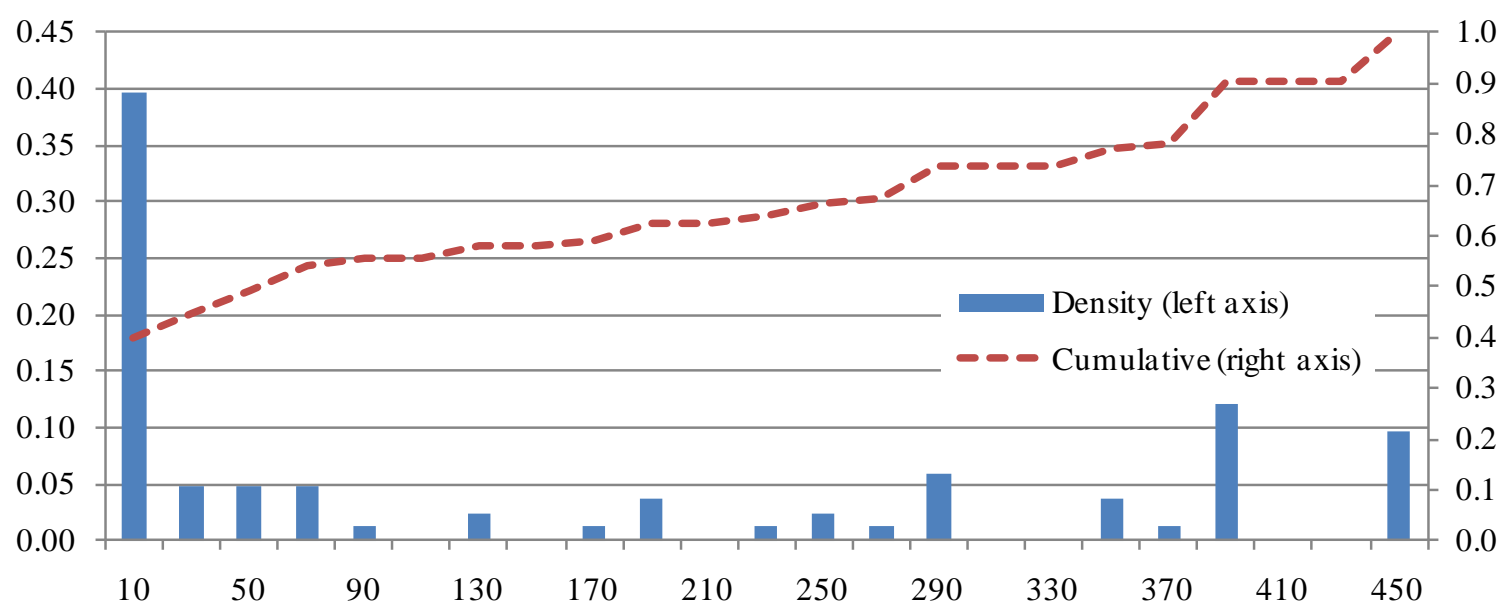

Histogram of Phone Survey Responses for "Typical APR in Your Area"

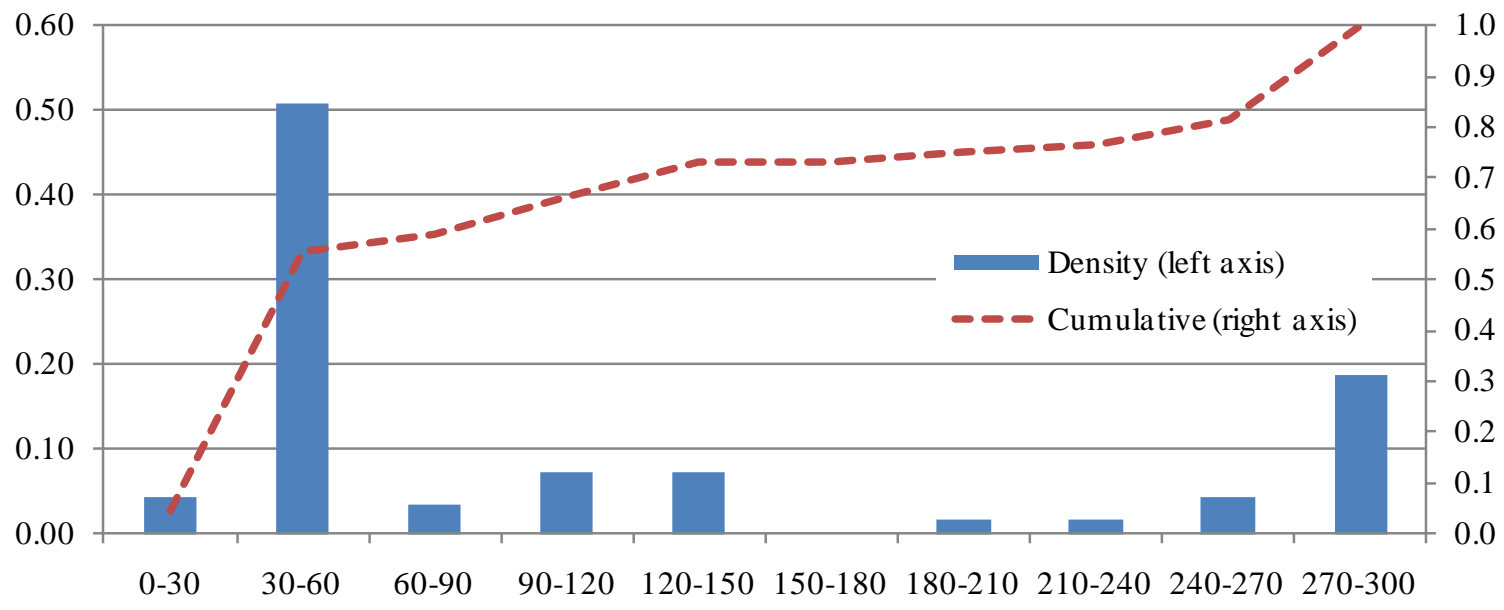

Histogram of Survey Responses for "Amount Paid in Fees for 3 Month \$300 Loan"

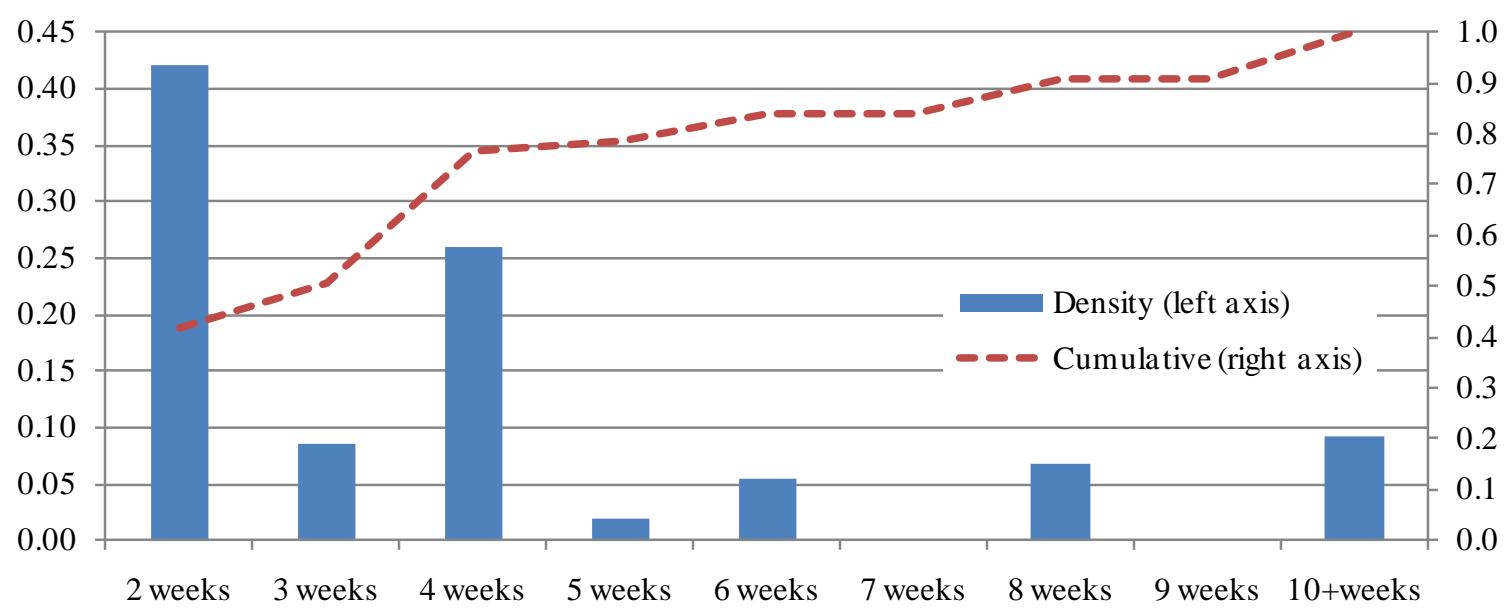

Histogram of Phone Survey Responses for "Typical Weeks Loans are Outstanding" 


\section{Table 1: Characteristics of Intervention Participants and Non-Participants}

\begin{tabular}{|c|c|c|c|}
\hline Characteristic of Borrower & Participants & Non-Participants & Lawrence \& Elliehausen \\
\hline \multicolumn{4}{|l|}{ Income Brackets } \\
\hline$<\$ 25,000$ & $42.7 \%$ & $35.2 \% *$ & $23.0 \% *$ \\
\hline$\$ 25,000-\$ 50,000$ & $44.6 \%$ & $47.8 \% *$ & $51.5 \% *$ \\
\hline$>\$ 50,000$ & $12.8 \%$ & $17.0 \% *$ & $25.4 \% *$ \\
\hline \multicolumn{4}{|l|}{ Age Brackets } \\
\hline$<35$ years & $32.0 \%$ & -- & $36.4 \%$ \\
\hline $35-44$ & $25.1 \%$ & -- & $31.9 \% *$ \\
\hline $45-54$ & $26.1 \%$ & -- & $21.7 \%$ \\
\hline $55-64$ & $12.9 \%$ & -- & $6.5 \% *$ \\
\hline$>64$ & $3.9 \%$ & -- & $3.5 \%$ \\
\hline \multicolumn{4}{|l|}{ Education Brackets } \\
\hline No High School Degree & $4.5 \%$ & -- & $6.2 \%$ \\
\hline High School Degree & $29.8 \%$ & -- & $38.3 \% *$ \\
\hline Some College & $49.6 \%$ & -- & $36.1 \% *$ \\
\hline College Degree & $15.7 \%$ & -- & $19.4 \%$ \\
\hline \multicolumn{4}{|l|}{ Pay Frequency Brackets } \\
\hline Weekly & $9.4 \%$ & $10.8 \% *$ & -- \\
\hline Bi-Weekly & $55.9 \%$ & $56.4 \%$ & -- \\
\hline Semi-Monthly & $15.9 \%$ & $14.3 \% *$ & -- \\
\hline Monthly & $18.7 \%$ & $18.5 \%$ & -- \\
\hline Average Number of Loans in Last 12 Months & 9.21 & 9.37 & $8.26 *$ \\
\hline Average Loan Amount in Last 12 Months & 372.5 & 366.3 & -- \\
\hline Average Total Fees Paid in Last 12 Months & 534.4 & -- & -- \\
\hline Observations & 1,441 & 5,199 & 427 \\
\hline Number of Stores & 71 & 71 & -- \\
\hline
\end{tabular}

Notes:

1. The participant data are from the download of lender records provided to us for consenting participants. The nonparticipants are borrowers using the payday service on the same days as our treatments who did not participate.

Lawrence and Ellihausen (2008) data are successes from a national phone survey.

2. An * indicates significantly different as compared to the participant column at the $5 \%$ confidence level or better. The Lawrence and Elliehausen comparison tests are proportion tests comparing their sample of 450 phone survey borrowers with our 1441 participants. The tests comparing our participants with borrowers at the same lender at the same stores and days are standard t-tests, where we draw a lognornal distribution of 5199 borrowers from the mean and number of observations for each store over the period (provided by the lender) and with a standard deviation equal to our participant standard deviation. 
Table 2: Effect of Information Treatments and Savings Planner on Indicator for Taking out a Loan

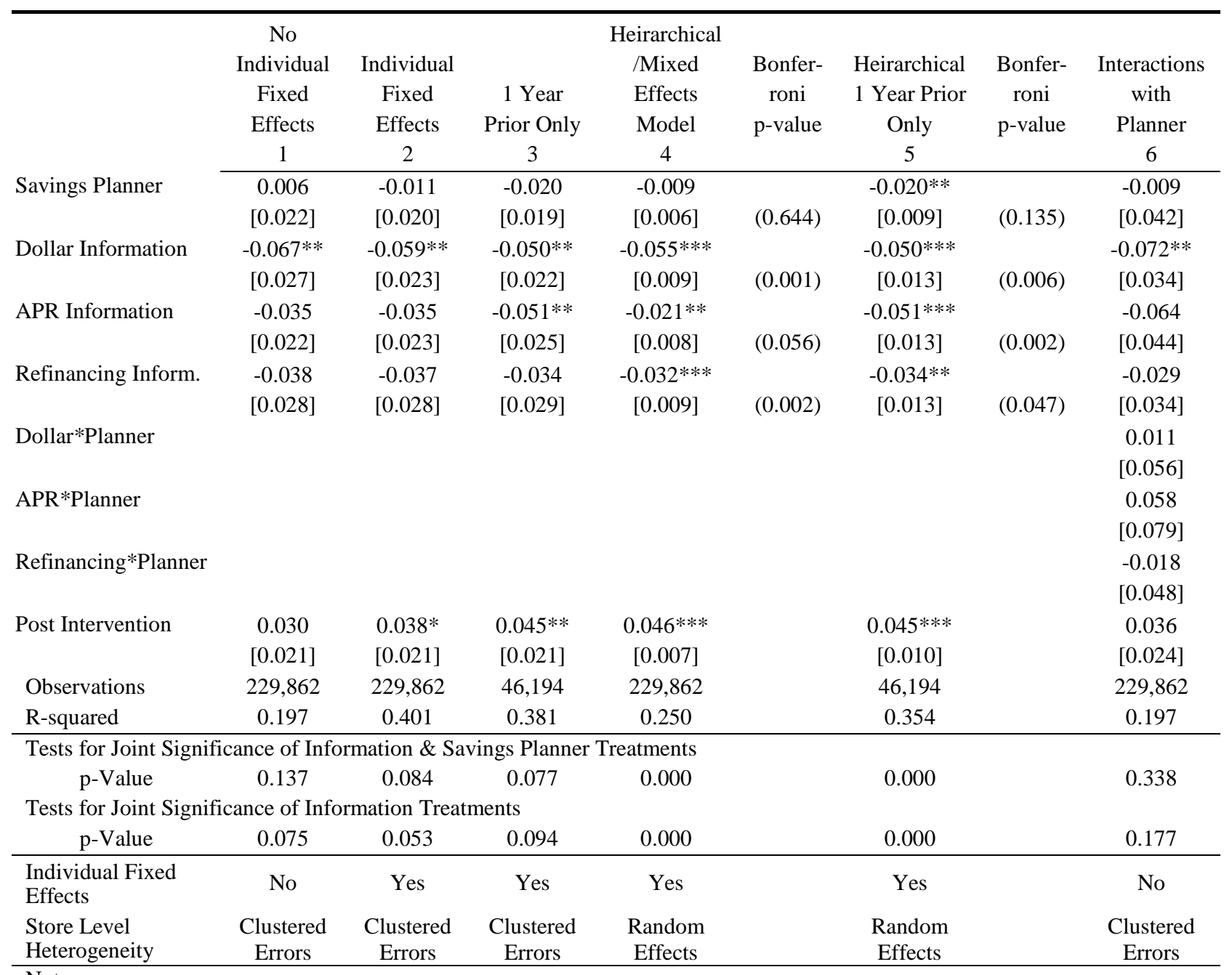

Notes:

1. The sample is a panel dataset and the unit of observation a given individual in a given payday cycle. For each individual, the last payday cycle included in the sample corresponds to the last cycle for which we obtained administrative records from the lender (see text for details). Columns 3 and 5 restrict the prior treatment period to being 1 year prior to treatment date.

2. The dependent variable equals 1 if the individual took a payday loan from the lender in the current payday cycle, 0 otherwise.

3. "Dollar Information” (“APR Information”; "Refinancing Information”; “Savings Planner”) is a dummy variable that equals 1 in all post-intervention pay cycles if the individual received the respective treatment, 0 otherwise. "Dollar*Planner" (“APR*Planner”; "Refinancing*Planner”) is a dummy variable that equals 1 in all post-intervention pay cycles if the individual received the "Dollar Information” (“APR Information”; “Refinancing Information”) treatment and a Savings Planner, 0 otherwise. "Post" is a dummy variable that equals 1 in all post-intervention pay cycles, 0 otherwise.

4. All regressions are estimated using least squares and include day of the week and store*year fixed effects. Brackets contain standard errors, robust for columns $4 \& 5$ and clustered for columns $1,2,3$, and 6 . *** indicates $\mathrm{p}<0.01 ; * * \mathrm{p}<0.05 ;{ }^{*} \mathrm{p}<0.1$. 5. Tests for joint significance of treatments are F-tests for the clustered standard error models (tested at the restricted standard errors) in columns 1,2,3, and 6 and are Chi-Square tests for the hierarchical/random effects columns 4 and 5 .

6. Bonferroni adjusted p-values are reported for the hierarchical models to account for the joint testing of the four treatments. 
Table 3: Effect of Information Treatments and Savings Planner on Amount Borrowed

\begin{tabular}{|c|c|c|}
\hline & $\begin{array}{c}\text { Tobit - Entire Sample } \\
1\end{array}$ & $\begin{array}{c}\text { Tobit - } 1 \text { Year Prior Only } \\
2\end{array}$ \\
\hline Savings Planner & $\begin{array}{c}10.55^{* * *} \\
{[2.409]}\end{array}$ & $\begin{array}{c}9.787 \\
{[19.23]}\end{array}$ \\
\hline Dollar Information & $\begin{array}{c}-54.83 * * * \\
{[2.063]}\end{array}$ & $\begin{array}{l}-43.83 * \\
{[22.78]}\end{array}$ \\
\hline APR Information & $\begin{array}{c}-38.48^{* * *} \\
{[2.450]}\end{array}$ & $\begin{array}{l}-32.04 * \\
{[18.08]}\end{array}$ \\
\hline Refinancing Inform. & $\begin{array}{c}-27.81 * * * \\
{[2.011]}\end{array}$ & $\begin{array}{c}-26.31 \\
{[23.27]}\end{array}$ \\
\hline Post Intervention & $\begin{array}{c}31.06 * * * \\
{[2.623]}\end{array}$ & $\begin{array}{c}26.53 \\
{[17.62]}\end{array}$ \\
\hline Payperiod Income & $\begin{array}{l}0.107 * * * \\
{[0.0002]}\end{array}$ & $\begin{array}{l}0.081 * * * \\
{[0.0084]}\end{array}$ \\
\hline Observations & 229,202 & 46,068 \\
\hline Pseudo R-Squared & 0.0624 & 0.0179 \\
\hline \multicolumn{3}{|c|}{ Tests for Joint Significance of Information and Savings Planner Treatments } \\
\hline p-Value & 0.009 & 0.006 \\
\hline \multicolumn{3}{|c|}{ Tests for Joint Significance of Information Treatments } \\
\hline p-Value & 0.006 & 0.004 \\
\hline Day of the Week Dummies & $\mathrm{Y}$ & $\mathrm{Y}$ \\
\hline Store*year Dummies & $\mathrm{Y}$ & $\mathrm{Y}$ \\
\hline Store Level Heterogeneity & Clustered & Clustered \\
\hline \multicolumn{3}{|c|}{ 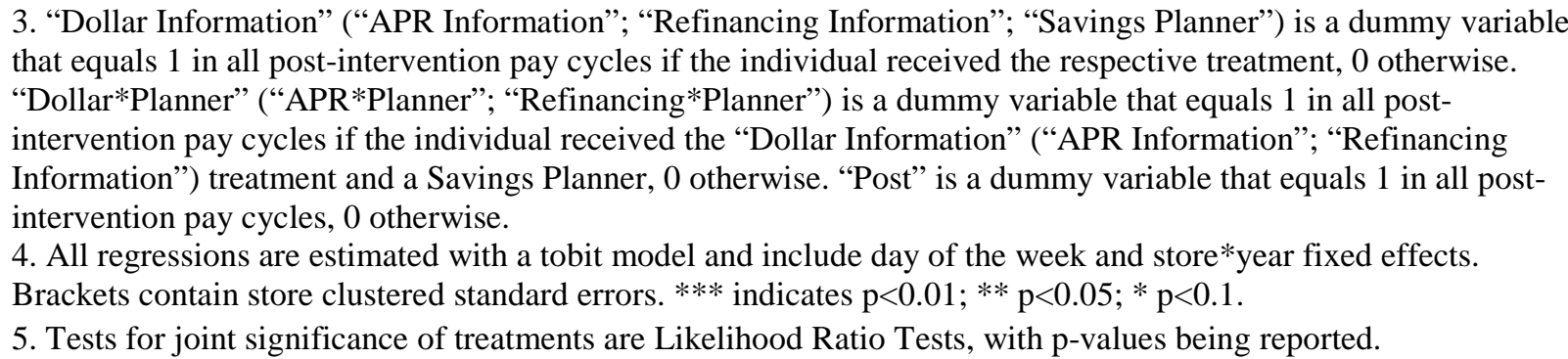 } \\
\hline
\end{tabular}


Table 4: Dynamic Effects of Treatments and Savings Planner on Payday Borrowing Activity

\begin{tabular}{|c|c|c|}
\hline Dependent Variable: & Least Squares - Indicator for Loan & Tobit - Loan Amount \\
\hline $\begin{array}{l}\text { Dollar Information * } \\
\qquad(\mathrm{t}=\text { intervention cycle }+1)\end{array}$ & $\begin{array}{c}-0.035 \\
{[0.033]}\end{array}$ & $\begin{array}{c}-7.137 \\
{[30.85]}\end{array}$ \\
\hline$(\mathrm{t}=$ intervention cycle +2$)$ & $\begin{array}{c}-0.064 * * \\
{[0.030]}\end{array}$ & $\begin{array}{c}-59.75^{* *} \\
{[25.62]}\end{array}$ \\
\hline$(t>$ intervention cycle +2$)$ & $\begin{array}{c}-0.057 * * \\
{[0.025]}\end{array}$ & $\begin{array}{c}-60.56 * * \\
{[30.52]}\end{array}$ \\
\hline $\begin{array}{l}\text { APR Information* } \\
\qquad(\mathrm{t}=\text { intervention cycle }+1)\end{array}$ & $\begin{array}{c}-0.036 \\
{[0.031]}\end{array}$ & $\begin{array}{l}-39.60 * \\
{[23.53]}\end{array}$ \\
\hline$(\mathrm{t}=$ intervention cycle +2$)$ & $\begin{array}{c}-0.065^{* *} \\
{[0.033]}\end{array}$ & $\begin{array}{l}-49.05^{*} \\
{[26.79]}\end{array}$ \\
\hline$(t>$ intervention cycle +2$)$ & $\begin{array}{l}-0.024 \\
{[0.027]}\end{array}$ & $\begin{array}{l}-31.97 \\
{[26.90]}\end{array}$ \\
\hline $\begin{array}{l}\text { Savings Planner* } \\
\qquad(\mathrm{t}=\text { intervention cycle }+1)\end{array}$ & $\begin{array}{c}-0.009 \\
{[0.023]}\end{array}$ & $\begin{array}{c}12.43 \\
{[20.36]}\end{array}$ \\
\hline$(\mathrm{t}=$ intervention cycle +2$)$ & $\begin{array}{l}-0.027 \\
{[0.023]}\end{array}$ & $\begin{array}{l}-11.56 \\
{[21.58]}\end{array}$ \\
\hline$(t>$ intervention cycle +2$)$ & $\begin{array}{l}-0.010 \\
{[0.023]}\end{array}$ & $\begin{array}{l}14.58 \\
{[27.92]}\end{array}$ \\
\hline $\begin{array}{l}\text { Refinancing Information* } \\
\qquad(\mathrm{t}=\text { intervention cycle }+1)\end{array}$ & $\begin{array}{l}-0.034 \\
{[0.034]}\end{array}$ & $\begin{array}{l}-28.63 \\
{[28.39]}\end{array}$ \\
\hline$(\mathrm{t}=$ intervention cycle +2$)$ & $\begin{array}{l}-0.049 \\
{[0.039]}\end{array}$ & $\begin{array}{l}-38.96 \\
{[32.42]}\end{array}$ \\
\hline$(t>$ intervention cycle +2$)$ & $\begin{array}{l}-0.030 \\
{[0.030]}\end{array}$ & $\begin{array}{l}-21.38 \\
{[33.18]}\end{array}$ \\
\hline $\mathrm{t}=$ intervention cycle +1 & $\begin{array}{c}0.204^{* * *} \\
{[0.028]}\end{array}$ & $\begin{array}{c}169.4 * * * \\
{[22.99]}\end{array}$ \\
\hline $\mathrm{t}=$ intervention cycle +2 & $\begin{array}{c}0.183^{* * *} \\
{[0.024]}\end{array}$ & $\begin{array}{c}162.7 * * * \\
{[21.35]}\end{array}$ \\
\hline $\mathrm{t}>$ intervention cycle +2 & $\begin{array}{l}-0.029 \\
{[0.023]}\end{array}$ & $\begin{array}{l}-34.12 \\
{[23.91]}\end{array}$ \\
\hline Store*year and day-of-the-week fixed effects & Yes & Yes \\
\hline Clustered Store Effects & Yes & Yes \\
\hline Observations & 229,862 & 229,202 \\
\hline R-squared & 0.404 & 0.050 \\
\hline
\end{tabular}

Notes:

1.The sample is a panel dataset and the unit of observation a given individual in a given payday cycle. For each individual, the last payday cycle included in the sample corresponds to the last cycle for which we obtained administrative records from the lender (see text for details).

2. The dependent variable for column 1 is "Indicator for Loan", a dummy variable that equals 1 if the individual took a payday loan from the lender in the current payday cycle, 0 otherwise. The dependent variable for column 2 is the loan amount taken out. Column 2 is estimated with a tobit model to handle the mass of zero amount loans.

2. "Dollar Information” (“APR Information”; "Refinancing Information”; "Savings Planner”) is a dummy variable that equals 1 in all post-intervention pay cycles if the individual received the respective treatment, 0 otherwise. "t=intervention cycle+1" ("t=intervention cycle+2"; " $>$ intervention cycle+2) is a dummy variable that equals one 1 (2; more than 2) pay cycle post intervention, 0 otherwise.

3. Standard errors, clustered at the store-level, are in brackets. ${ }^{* * *}$ indicates $\mathrm{p}<0.01$; ${ }^{* *} \mathrm{p}<0.05 ;{ }^{*} \mathrm{p}<0.1$. 
Table 5: Effect of Information Treatments with Splits by Individual Heterogeneities

\begin{tabular}{|c|c|c|c|c|c|c|c|c|c|}
\hline & $\begin{array}{c}\text { High } \\
\text { School or } \\
\text { Less } \\
(1)\end{array}$ & $\begin{array}{c}\text { Some } \\
\text { College but } \\
\text { No Degree } \\
\text { (2) }\end{array}$ & $\begin{array}{l}\text { College } \\
\text { Degree or } \\
\text { More } \\
(3)\end{array}$ & $\begin{array}{l}\text { Low Self } \\
\text { Control } \\
\text { Scale } \\
(4)\end{array}$ & $\begin{array}{l}\text { High Self } \\
\text { Control } \\
\text { Scale } \\
(5)\end{array}$ & $\begin{array}{l}\text { Not Gratifi- } \\
\text { cation } \\
\text { Usage } \\
(6)\end{array}$ & $\begin{array}{l}\text { Grati- } \\
\text { fication } \\
\text { Usage } \\
\text { (7) }\end{array}$ & $\begin{array}{c}\text { Long } \\
\text { Expected } \\
\text { Loan Time } \\
\text { (8) }\end{array}$ & $\begin{array}{c}\text { Not Long } \\
\text { Expected } \\
\text { Loan Time } \\
\text { (9) }\end{array}$ \\
\hline Savings Planner & $\begin{array}{c}-0.009 \\
{[0.035]}\end{array}$ & $\begin{array}{c}0.027 \\
{[0.037]}\end{array}$ & $\begin{array}{c}-0.047 \\
{[0.044]}\end{array}$ & $\begin{array}{c}0.008 \\
{[0.032]}\end{array}$ & $\begin{array}{c}0.008 \\
{[0.028]}\end{array}$ & $\begin{array}{c}0.007 \\
{[0.023]}\end{array}$ & $\begin{array}{c}-0.018 \\
{[0.067]}\end{array}$ & $\begin{array}{c}0.019 \\
{[0.037]}\end{array}$ & $\begin{array}{c}-0.005 \\
{[0.023]}\end{array}$ \\
\hline Dollar Information & $\begin{array}{c}-0.082 \\
{[0.052]}\end{array}$ & $\begin{array}{c}-0.113^{* * *} \\
{[0.038]}\end{array}$ & $\begin{array}{c}0.083 \\
{[0.076]}\end{array}$ & $\begin{array}{c}-0.025 \\
{[0.043]}\end{array}$ & $\begin{array}{c}-0.093 * * * \\
{[0.034]}\end{array}$ & $\begin{array}{c}-0.071^{* *} \\
{[0.028]}\end{array}$ & $\begin{array}{c}0.001 \\
{[0.101]}\end{array}$ & $\begin{array}{c}-0.043 \\
{[0.048]}\end{array}$ & $\begin{array}{c}-0.069 * \\
{[0.037]}\end{array}$ \\
\hline APR Information & $\begin{array}{c}0.013 \\
{[0.045]}\end{array}$ & $\begin{array}{c}-0.066^{*} \\
{[0.037]}\end{array}$ & $\begin{array}{c}-0.033 \\
{[0.102]}\end{array}$ & $\begin{array}{c}-0.074 * * \\
{[0.035]}\end{array}$ & $\begin{array}{c}0.001 \\
{[0.035]}\end{array}$ & $\begin{array}{c}-0.040^{*} \\
{[0.023]}\end{array}$ & $\begin{array}{c}-0.008 \\
{[0.079]}\end{array}$ & $\begin{array}{c}-0.080 \\
{[0.056]}\end{array}$ & $\begin{array}{c}-0.011 \\
{[0.029]}\end{array}$ \\
\hline Refinancing Information & $\begin{array}{c}-0.054 \\
{[0.048]}\end{array}$ & $\begin{array}{c}-0.029 \\
{[0.045]}\end{array}$ & $\begin{array}{c}-0.049 \\
{[0.096]}\end{array}$ & $\begin{array}{c}-0.053 \\
{[0.039]}\end{array}$ & $\begin{array}{c}-0.023 \\
{[0.041]}\end{array}$ & $\begin{array}{c}-0.047 \\
{[0.029]}\end{array}$ & $\begin{array}{c}0.017 \\
{[0.083]}\end{array}$ & $\begin{array}{c}-0.042 \\
{[0.049]}\end{array}$ & $\begin{array}{c}-0.020 \\
{[0.037]}\end{array}$ \\
\hline $\begin{array}{l}\text { Observations } \\
\text { R-squared }\end{array}$ & $\begin{array}{c}80,884 \\
0.387\end{array}$ & $\begin{array}{c}113,405 \\
0.367\end{array}$ & $\begin{array}{c}34,260 \\
0.335\end{array}$ & $\begin{array}{c}106,063 \\
0.350\end{array}$ & $\begin{array}{c}123,799 \\
0.383\end{array}$ & $\begin{array}{c}20,182 \\
0.383\end{array}$ & $\begin{array}{c}209,680 \\
0.367\end{array}$ & $\begin{array}{c}92,073 \\
0.223\end{array}$ & $\begin{array}{c}137,789 \\
0.332\end{array}$ \\
\hline $\begin{array}{l}\text { Day of Week Fixed Effects } \\
\& \text { Store*year Fixed Effects }\end{array}$ & Yes & Yes & Yes & Yes & Yes & Yes & Yes & Yes & Yes \\
\hline Store Clustered Errors & Yes & Yes & Yes & Yes & Yes & Yes & Yes & Yes & Yes \\
\hline
\end{tabular}

Notes:

1. The sample is a panel dataset and the unit of observation a given individual in a given payday cycle. For each individual, the last payday cycle included in the sample corresponds to the last cycle for which we obtained administrative records from the lender (see text for details).

2. The dependent variable for all columns is "Indicator for Loan", a dummy variable that equals 1 if the individual took a payday loan from the lender in the current payday cycle, 0 otherwise.

3. "Dollar Information” (“APR Information”; "Refinancing Information”; "Savings Planner”) is a dummy variable that equals 1 in all post-intervention pay cycles if the individual received the "Dollar Information” (“APR Information”; "Refinancing Information”; "Savings Planner”) treatment, 0 otherwise.

4. All regressions are estimated using least squares and include store*year and day-of-the-week fixed effects and an indicator for the post period. Standard errors are clustered at the store-level.

5. We categorize under "Self-Reported Usage of Loan is Gratification" those individuals that reported planning to use their payday loan in the survey we conducted in the store for either: gifts, apparel, electronics, eating out or vacation. All other usages are categorized under "Not Gratification." The other usages were rent, utilities, medical bills, personal emergencies, transportation and car expenses, groceries, other debt, other bills and other. Slightly over half of the individuals chose more than one category. In such a case, we coded gratification equal to one if one of the gratification items was checked.

6. We categorize as "Self-Reported Self-Control is High" those individuals that scored above the median on the impulsivity self-assessment portion of the survey taken from Puri (2001). Individuals were asked to rate themselves from 1 (seldom describes me) to 7 (usually describes me) on four attributes - a planner, impulsive, self-controlled, and enjoy spending. The scale $=+$ a planner + self-controlled - impulsivity - enjoys spending, and is thus increasing in self-control.

7. Expected time to payback loan is coded long if the individual reports a payback time greater than 1.33 the pay cycle length.

8.Standard errors, clustered at the store-level, are in brackets. ${ }^{* * *}$ indicates $\mathrm{p}<0.01 ;{ }^{* *} \mathrm{p}<0.05 ;{ }^{*} \mathrm{p}<0.1$. 
